\title{
Hasil Belajar Konsep Pereaksi Pembatas Berbantuan LKS-Induktif Pada Siswa Kelas X SMA Negeri 1 Palangka Raya Tahun Pelajaran 2018/2019
}

\author{
Ike Valentie ${ }^{1 *}$, Abdul Hadjranul Fatah ${ }^{2}$ \\ ${ }^{1}$ SMA Negeri 1 Palangka Raya, Kalimantan Tengah, Indonesia \\ ${ }^{2}$ Pogram Studi Pendidikan Kimia, Universitas Palangka Raya, Indonesia \\ Email: ike.valentie@yahoo.co.id
}

Diterima: 03 Mei 2020; Disetujui: 11 Mei 2020; Diterbitkan: 12 Mei 2020

\begin{abstract}
ABSTRAK
Stoikiometri atau perhitungan kimia membahas beberapa konsep, salah satunya adalah pereaksi pembatas. Siswa mempelajari materi pereaksi pembatas perlu memahami dan menguasai konsep prasyarat yakni rumus kimia, persamaan kimia dan konsep mol. Akar penyebab rendahnya kemampuan penalaran konsep pereaksi pembatas dapat bersumber dari guru, siswa dan lingkungan. Berdasarkan beberapa hal itu diperlukan strategi pembelajaran yang tepat di mana guru tidak menyajikan materi yang bersifat abstrak tetapi membimbing siswa berpikir dalam melakukan penalaran untuk memperoleh pengetahuan baru. Salah satunya dengan menggunakan Lembar Kerja Siswa (LKS). Pembelajaran yang menggunakan LKS-induktif untuk dapat meningkatkan aktivitas belajar siswa secara optimal dan sekaligus memotivasi siswa untuk berpikir kritis. Pembelajaran menggunakan LKS-induktif berpengaruh terhadap kemampuan siswa dalam memahami konsep pereaksi pembatas. Penelitian ini bertujuan untuk: mendeskripsikan hasil belajar berbantuan LKS-Induktif dalam pembelajaran kimia terhadap pemahaman konsep pereaksi pembatas. Penelitian ini melibatkan 68 siswa kelas X MIPA-5 dan X MIPA-7 SMA Negeri 1 Palangka Raya. Instrumen yang digunakan adalah lembar soal pretes dan postes, lembar isian jawaban latihan pada LKS-Induktif. Data dikumpulkan melalui tiga tahap yaitu pretes, pelaksanaan pembelajaran berbantuan LKS-Induktif, dan postes. Data yang diperoleh dianalisis secara deskriptif. Hasil penelitian menunjukkan bahwa siswa mampu: (a) menerapkan konsep prasyarat sebesar $88 \%$; (b) memahami definisi pereaksi pembatas sebesar $78,2 \%$; dan (c) menentukan pereaksi pembatas yang dikonversi dari massa, volume, atau jumlah partikel zat yang diketahui sebesar $71,87 \%$.
\end{abstract}

Kata kunci: Hasil belajar, Pereaksi Pembatas, LKS-Induktif

\section{PENDAHULUAN}

Belajar adalah proses berpikir. Belajar berpikir merupakan proses siswa mencari dan memperoleh pengetahuannya sendiri melalui interaksi antara individu dengan lingkungan (Sanjaya, 2010). Usaha-usaha siswa memperoleh pengetahuan akan menumbuhkan kemampuan berpikir. Menurut Peter Reason (Sanjaya, 2010) berpikir adalah proses mental seseorang yang lebih dari sekedar mengingat, memahami. Belajar berpikir menyebabkan seseorang belajar lebih dari mengingat dan memahami untuk menemukan solusi baru dari persoalan yang dihadapinya. Pelajaran kimia merupakan salah satu pelajaran yang menggunakan 
keterampilan dalam memecahkan masalah dengan menggunakan fakta, konsep, prinsip, hukum dan teori. Pembelajaran yang dimulai dari masalah-masalah aktual, otentik menuntut keaktifan siswa memperoleh suatu informasi dan pemecahan masalah sehingga mampu membuktikan kebenaran suatu konsep. Middlecamp \& Kean (1995) menyatakan bahwa ilmu kimia memiliki beberapa karakteristik yang khas, antara lain: (1) sebagian besar materi kimia bersifat abstrak $_{2}$ yaitu konsep yang termasuk pada tataran mikroskopis (seperti atom, molekul, elektron dan ikatan kimia), untuk memahami konsep mikroskopis dapat dipelajari melalui gambar. Penggambaran bukan dimaksudkan untuk memberikan gambaran obyek yang sebenarnya, melainkan mencoba menekankan ciri-ciri khusus dari obyek-obyek yang bersifat abstrak; (2) ilmu kimia merupakan penyederhanaan dari yang sebenarnya; (3) materi kimia tidak hanya sekedar memecahkan soal-soal secara konsep matematis, melainkan harus mempelajari diskripsi kimia, peristilahan khusus dan aturan-aturan kimia.

Materi pereaksi pembatas merupakan bagian dari Stoikiometri yang dipelajari siswa diakhir materi stoikiometri. Artinya untuk mempelajari materi pereaksi pembatas siswa sudah memahami dan menguasai hukum-hukum dasar yang meliputi hukum kekekalan massa, hukum perbandingan tetap, hukum perbandingan berganda, hukum perbandingan volume, hipotesis Avogadro, dan konsep mol. Hukum kekekalan massa menyatakan massa sebelum reaksi sama dengan massa sesudah reaksi. Banyaknya zat pereaksi ataupun produk diperoleh jika persamaan reaksi sudah setara.

Materi pereaksi pembatas terdiri dari dua konsep yaitu konsep konkrit dan konsep abstrak. Konsep yang bersifat abstrak membutuhkan penjelasan pada level mikroskopis. Level mikroskopis tidak dapat dipisahkan dari dua level lainnya yaitu level simbolis dan level makroskopis karena mengandung informasi yang saling terkait. Pentingnya peranan tiga level pada proses pembelajaran di SMA supaya guru tidak cenderung menggunakan metode ceramah.

Salah satu masalah yang dihadapi dunia pendidikan adalah dalam proses pembelajaran, siswa kurang didorong mengembangkan kemampuan berpikir. Proses pembelajaran menjadi kurang kondusif disebabkan metode ceramah kurang melibatkan keaktifan siswa dalam proses pembelajaran. Materi pereaksi pembatas merupakan bagian dari stoikiometri (perhitungan kimia) tidak efektif bila diajarkan dengan metode ceramah sebab karakter materi pereaksi pembatas bersifat abstrak memerlukan keterampilan berpikir kritis untuk memahaminya.

Pengetahuan tentang pereaksi pembatas merupakan pengetahuan konseptual dan prosedural. Menurut Hilbert (Rivai, 2013) pengetahuan konseptual dapat diartikan sebagai suatu jaringan pengetahuan yang menghubungkan penggalanpenggalan informasi yang telah tersimpan di dalam memori atau antara suatu penggalan pengetahuan yang telah ada dengan yang baru dipelajari. Pengetahuan konseptual mencakup klasifikasi, bentuk, konsep, bentuk, struktur. Pemahaman konsep pereaksi pembatas menghubungkan dengan konsep mol, persamaan reaksi, rumus kimia. Pengetahuan prosedural adalah pengetahuan yang dibentuk dari algoritma-algoritma atau aturan-aturan untuk menyelesaikan soal-soal hitungan kimia.

Faktor penyebab rendahnya kemampuan penalaran belajar kimia bersumber pada guru, siswa dan lingkungan. Penyebab yang paling dominan yaitu guru 
dalam pembelajaran terlalu monoton dan pembelajaran hanya berpusat pada guru, strategi pembelajaran kurang inovatif dan metode pembelajaran kurang bervariasi sehingga pembelajaran kurang menarik bagi siswa.

Permendiknas 81 A tahun 2013 dikemukakan bahwa untuk membudayakan berpikir secara kritis pada siswa, maka guru sebagai fasilitator haruslah memberikan kesempatan kepada siswa untuk berperan aktif dalam proses pembelajaran.

Diperlukan strategi pembelajaran yang tepat di mana guru tidak menyajikan materi yang bersifat abstrak tetapi membimbing siswa berpikir dalam melakukan penalaran untuk memperoleh pengetahuan baru. Agar siswa dapat melakukan penalaran secara efektif maka perlu media.

Salah satunya dengan menggunakan Lembar Kerja Siswa (LKS). LKS berisi petunjuk dan langkah-langkah untuk menyelesaikan suatu tugas seperti yang diungkapkan Rustaman (Madjid, 2013). Uno (2006) mengemukakan bahwa LKS harus dibuat perencanaannya sehingga kegiatan belajar mengajar menjadi kreatif dan inovatif serta efektif dalam mencapai tujuan yang telah ditetapkan serta dapat membantu siswa aktif. Pembelajaran menggunakan LKS-induktif untuk mengaktifkan siswa secara optimal dan memotivasi siswa untuk berpikir kritis, sehingga berpengaruh terhadap kemampuan siswa dalam memahami konsep pereaksi pembatas. Penggunaan LKS-induktif untuk memahami informasi yang bersifat khusus, berupa pernyataan khusus mengenai pereaksi pembatas agar selanjutnya menarik kesimpulan yang bersifat umum berdasarkan data yang diamati. Hasil penelitian Valentie (2019) menunjukkan pemahaman konsep pereaksi pembatas siswa kelas $\mathrm{X}$ rata-rata kurang dari $70 \%$.

Berdasarkan uraian di atas, maka perlu dilakukan penelitian untuk mengetahui hasil belajar konsep pereaksi pembatas menggunakan LKS-induktif pada siswa kelas X SMA Negeri 1 Palangka Raya tahun pelajaran 2018/2019.

Berdasarkan uraian di atas, dapat diidentifikasi masalah terkait dengan hasil belajar konsep pereaksi pembatas menggunakan LKS-induktif, yaitu:

1. Keaktifan siswa dalam proses pembelajaran masih kurang.

2. Rendahnya hasil belajar terhadap konsep-konsep kimia.

3. Proses pembelajaran kurang kondusif sebab guru lebih sering menggunakan metode ceramah.

4. Model pembelajaran yang digunakan belum disesuaikan dengan karakter materi pelajaran.

Masalah ini dibatasi hasil belajar konsep siswa dilihat dari hasil pretes dan postes siswa pada konsep pereaksi pembatas mendefinisikan pengertian pereaksi pembatas, dan konsep pereaksi pembatas ke dalam perhitungan kimia untuk menentukan pereaksi pembatas dengan interkonversi massa pereaksi atau dari volume pereaksi, jumlah partikel, molaritas ke dalam satuan mol melalui penalaran induktif dengan bantuan lembar kerja siswa.

Berdasarkan latar belakang masalah, permasalahan dalam penelitian ini dirumuskan sebagai berikut: Bagaimana hasil belajar konsep pereaksi pembatas menggunakan LKS-induktif pada siswa kelas X SMA Negeri 1 Palangka Raya tahun pelajaran 2018/2019?

Adapun tujuan penelitian ini adalah mendeskripsikan hasil belajar konsep siswa SMA Negeri 1 Palangka Raya mengenai pereaksi pembatas sebelum dan sesudah pembelajaran menggunakan LKS-induktif. 
Manfaat ini secara teoritis diharapkan dapat memberikan sumbangan pemikiran dalam pengembangan sistem pembelajaran, dan memperkaya kajian untuk sumber bacaan tentang pereaksi pembatas. Manfaat praktis penelitian ini diharapkan dapat sebagai sumbangan pemikiran bagi guru dalam merencanakan pembelajaran dengan menggunakan LKS- induktif, dan menjadi sarana informasi untuk melakukan penelitian lebih lanjut.

\section{METODOLOGI PENELITIAN}

Penelitian ini merupakan penelitian deskriftif, menggambarkan secara jelas mengenai perubahan pemahaman konsep siswa tentang pereaksi pembatas dalam pembelajaran dengan menerapkan model LKS-Induktif.

Penelitian ini dilaksanakan di SMAN 1 Palangka Raya pada akhir semester genap tahun pelajaran 2018/2019. Penelitian dilakukan pada siswa kelas X yang belum mempelajari materi pereaksi pembatas.

Penelitian dilaksanakan di SMA Negeri 1 Palangka Raya. Terdapat 7 kelas X MIPA di sekolah ini. Dari populasi dipilih kelas sebagai sampel penelitian dengan menggunakan teknik acak kelompok (random sampling). Berdasarkan teknik tersebut terpilih kelas sebagai subjek penelitian ini adalah kelas X MIPA -5 dan X MIPA-7.

Data yang diperlukan untuk menjawab masalah penelitian ini adalah untuk memperoleh data tersebut perlu disiapkan instrumen. Dari penyusunan instrumen, data yang diperoleh untuk penelitian ini meliputi data pemahaman konsep, LKS dan lembar pengamatan aktivitas belajar siswa dan wawancara.

Instrumen lain yang digunakan saat pelaksanaan pembelajaran berlangsung adalah LKS. Instrumen tersebut disusun berdasarkan silabus mata pelajaran kimia kelas $\mathrm{X}$ dan dikembangkan sesuai dengan indikator bertujuan untuk mengarahkan siswa mencari dan menemukan konsep pereaksi pembatas.

Langkah-langkah dalam pembelajaran pereaksi pembatas menggunakan LKS induktif sebagai berikut:

a) Siswa menerapkan konsep yang telah dipelajari sebagai konsep prasyarat. Konsep-konsep tersebut yaitu persamaan reaksi dan perbandingan tetap. Penguasaan konsep persamaan reaksi meliputi materi pereaksi dan hasil reaksi, serta mampu menyetarakan reaksi. Penyetaraaan reaksi berkaitan dengan hukum Lavoiser.

b) Langkah berikutnya siswa menentukan zat sebagai pereaksi pembatas dengan menerapkan perbandingan mol/atom dan perbandingan koefisien ke dalam suatu persamaan reaksi berdasarkan gambar (simbolik). Perbandingan mol atau atom suatu pereaksi sesuai dengan perbandingan koefisien akan didapatkan pereaksi yang habis bereaksi.

c) Soal hitungan kimia menggunakan pereaksi pembatas diselesaikan dengan algoritma, menunjukkan pereaksi yang habis bereaksi (pereaksi pembatas) dan pereaksi yang tersisa sehingga diperoleh konsep menentukan zat yang bertindak sebagai pereaksi pembatas dari data massa, volume atau jumlah partikel.

Data dikumpulkan melalui tahapan-tahapan sebagai berikut:

1) Memberikan tes awal (Pretes) yang bertujuan untuk memperoleh data pemahaman dan kemampuan awal siswa dalam menyelesaikan soal pereaksi pembatas yang akan dipelajari, 
2) Dilanjutkan pembelajaran menggunakan LKS-Induktif,

3) Tahap terakhir pembelajaran adalah pemberian tes akhir (Postes). Tes akhir bertujuan untuk menjaring data kemampuan siswa memahami materi setelah pembelajaran menggunakan LKS-Induktif.

Bagi siswa yang tidak mengalami perubahan hasil pretes dan postes maka dilakukan wawancara terhadap siswa tersebut.

Persentase Pemahaman Konsep untuk setiap siswa:

$$
\mathrm{P} \text { Siswa }=\frac{\sum \text { skor yang diperoleh siswa }}{\sum \text { Skor maksimum }} \times 100 \%
$$

Persentase pemahaman konsep siswa sebelum pembelajaran (pretes) dan sesudah pembelajaran (postes) dibandingkan sehingga dapat diketahui pemahaman konsep siswa dalam pembelajaran mengalami peningkatan atau tidak, dan dapat diklasifikasikan peningkatan pemahamannya.

Data yang diperlukan dalam hasil belajar LKS-Induktif dianalisis secara deskriptif untuk mendeskripsikan hasil belajar siswa tentang pereaksi pembatas menggunakan LKS-Induktif. Persentase Hasil Belajar Pemahaman Konsep menggunakan LKS-Induktif untuk setiap siswa:

$\mathrm{P}$ Siswa $=\frac{\sum \text { skor yang diperoleh siswa }}{\sum \text { Skor maksimum }} \times 100 \%$

Acuan yang digunakan untuk hasil belajar memahami konsep pereaksi pembatas dalam pembelajaran menggunakan LKS-induktif.

\section{HASIL PENELITIAN DAN PEMBAHASAN}

Hasil Penelitian meliputi:

1) Hasil pelaksanaan pembelajaran.

Penelitian dilaksanakan di kelas X SMA Negeri 1 Palangka Raya pada akhir semester genap tahun pelajaran 2018/2019, dengan pengambilan data penelitian pada tanggal 16 dan 18 Mei 2019 disesuaikan dengan jadwal pelajaran. Subjek penelitian yang terpilih dengan teknik acak kelompok adalah siswa-siswa kelas X MIPA-5 dan X MIPA-7 sebanyak 68 siswa, namun pada pelaksanaannya ada 6 siswa yang tidak hadir, sehingga diperoleh data penelitian dari 68 siswa. Dilakukan dengan tahap pertama pemberian pretes. Tahap kedua adalah guru melakukan pembelajaran menggunakan LKSInduktif dikerjakan siswa secara mandiri dalam kelompok. Tahap selanjutnya pemberian postes berisikan soal yang berbeda dengan soal pretes, tetapi memiliki bobot nilai yang sama. Pergeseran pemahaman konsep siswa dapat dilihat nilai tes yang diperoleh sebelum dan sesudah pembelajaran menggunakan LKS-Induktif. Siswa yang tidak mengalami pergeseran pemahaman dilakukan wawancara pasca pembelajaran dan di luar jam pelajaran dengan menanyakan hal-hal yang diperlukan, untuk mengetahui pemahaman siswa yang lebih mendalam.

2) Hasil data pretes dan postes.

Hasil pretes diperoleh skor minimum pretes adalah 0 dan skor tertinggi 6,9. Nilai rata-rata pretes siswa adalah $1,62 \%$ dengan kategori tingkat pemahaman kurang sekali. Hal ini terjadi karena siswa belum pernah mempelajari konsep Pereaksi Pembatas. Setelah pretes dilanjutkan pada kegiatan pembelajaran menggunakan LKS-Induktif, kemudian dilaksanakan pemberian postes setelah pembelajaran berakhir. Skor terrendah untuk postes 
adalah 10,34 dan skor tertertinggi 100. Nilai rata-rata postest yang diperoleh siswa sebesar $65,82 \%$ dengan kategori tingkat pemahaman baik, menunjukkan adanya peningkatan pemahaman konsep siswa setelah mempelajari konsep Pereaksi Pembatas menggunakan LKS-Induktif.

Pasca pembelajaran menggunakan LKS-Induktif, semua siswa mengalami peningkatan pemahaman. Hal ini dapat dilihat dari rata-rata nilai siswa saat postes yaitu 64,34 dan 69,32. Jumlah peningkatan persentase siswa yang menjawab benar yaitu 52,58 dan 69,32 masing-masing untuk indikator mendefinisikan pengertian pereaksi pembatas dan indikator menentukan pereaksi pembatas.

3) Deskripsi data kemampuan belajar siswa memahami konsep Pereaksi Pembatas dalam pembelajaran dengan LKS-Induktif.

Pelaksanaan pembelajaran pada penelitian ini meliputi beberapa tahapan yang dilakukan sesuai dengan tahapan pada pembelajaran, yaitu kegiatan pendahuluan. Selanjutnya, dalam kegiatan inti guru membagi kelompok yang terdiri dari 4 orang dalam satu kelompok, dan LKS-Induktif diberikan kepada setiap kelompok untuk didiskusikan. Hal ini bertujuan mengetahui sejauh mana kemampuan siswa menerapkan konsep yang akan dipelajari dengan saling bekerjasama mengerjakan LKS-Induktif, berdiskusi, tanya jawab antar sesama teman. Akhir kegiatan pembelajaran guru memberikan postes yang bertujuan untuk mengetahui peningkatan pemahaman konsep setelah pembelajaran menggunakan LKSInduktif pada materi Pereaksi Pembatas.

Deskripsi Hasil Belajar Siswa Menggunakan LKS-Induktif.

Perubahan pemahaman konsep siswa juga didukung oleh aktivitas belajar secara kelompok. Hasil belajar (aktivitas belajar kelompok) berbantuan LKSInduktif yang baik, maka kecenderungan pemahaman konsep pun meningkat. Materi pereaksi pembatas berbantuan LKS-Induktif dipelajari dengan langkahlangkah berikut:

1) Menerapkan konsep prasyarat

Konsep sebagai prasyarat adalah perbandingan tetap (A) dan persamaaan reaksi (B).

Tabel 1. Distribusi Skor Perbandingan Tetap (A)

\begin{tabular}{ccc}
\hline Skor & Frekuensi & Hasil Belajar LKS(\%) \\
\hline 0 & 6 & 9 \\
1 & 62 & 91 \\
Jumlah & 68 & 100 \\
\hline
\end{tabular}

Tabel 2. Distribusi Skor Persamaan Reaksi (B)

\begin{tabular}{ccc}
\hline Skor & Frekuensi & Hasil Belajar LKS(\%) \\
\hline 0 & 10 & 15 \\
1 & 58 & 85 \\
Jumlah & 68 & 100 \\
\hline
\end{tabular}

Diperoleh persentase konsep prasyarat adalah sebagi berikut: 
Tabel 3. Persentase Konsep Prasyarat

\begin{tabular}{cc}
\hline Konsep Prasyarat & Persentase(\%) \\
\hline Konsep A & 91 \\
Konsep B & 85 \\
Rerata & 88 \\
\hline
\end{tabular}

2) Mendefinisikan pereaksi pembatas

Diperoleh persentase kegiatan mendefinisikan pereaksi pembatas adalah sebagai berikut:

Tabel 4. Persentase Mendefinisikan Pereaksi Pembatas

\begin{tabular}{|c|c|}
\hline Kegiatan Mendefinisikan Pereaksi Pembatas & $\begin{array}{c}\text { Persentase } \\
(\%)\end{array}$ \\
\hline $\begin{array}{l}\text { menghitung perbandingan mol pereaksi-pereaksi suatu } \\
\text { persamaan reaksi }(\mathrm{C})\end{array}$ & 100 \\
\hline $\begin{array}{l}\text { menghitung perbandingan koefisien pereaksi-pereaksi tersebut } \\
\text { (D) }\end{array}$ & 52,8 \\
\hline $\begin{array}{l}\text { mengamati adanya pereaksi yang habis bereaksi apabila } \\
\text { perbandingan mol sesuai dengan perbandingan koefisiennya } \\
\text { (E) }\end{array}$ & 80 \\
\hline mendefinisikan pereaksi pembatas $(\mathrm{F})$ & 80 \\
\hline Rerata & 78,2 \\
\hline
\end{tabular}

3) Menentukan Pereaksi Pembatas

Diperoleh persentase kegiatan menentukan pereaksi pembatas adalah sebagai berikut:

Tabel 5. Persentase Menentukan Pereaksi Pembatas

\begin{tabular}{lc}
\hline Kegiatan Menentukan Pereaksi Pembatas & $\begin{array}{c}\text { Persentase } \\
(\%)\end{array}$ \\
\hline $\begin{array}{l}\text { menuliskan banyaknya mol atau massa atau volume pada } \\
\text { keadaan STP atau jumlah partikel ataupun molaritas dari data }\end{array}$ & 100 \\
$\begin{array}{l}\text { yang disajikan pada suatu reaksi (G) } \\
\text { mengkonversi mol dari massa atau volume pada keadaan }\end{array}$ & 100 \\
$\begin{array}{l}\text { standar atau jumlah partikel ataupun molaritas (H) } \\
\text { menghitung mol masing-masing pereaksi dibagi dengan } \\
\text { koefisiennya (I) }\end{array}$ & 56,1 \\
$\begin{array}{l}\text { membandingkan nilai hasil bagi mol dengan koefisien kedua } \\
\text { pereaksi (J) }\end{array}$ & 34 \\
$\begin{array}{l}\text { membuktikan ada pereaksi pembatas jika pereaksi tersebut } \\
\text { memiliki nilai hasil bagi mol dengan koefisien lebih kecil dari } \\
\text { hasil bagi mol dengan koefisien pereaksi lain (K) } \\
\text { menyimpulkan pereaksi pembatas sebagai pereaksi yang } \\
\text { memiliki nilai hasil bagi mol dengan koefisien lebih kecil dari } \\
\text { hasil bagi mol dengan koefisien pereaksi lain (L) } \\
\quad \text { Rata-rata }(\%)\end{array}$ & 56,1 \\
\hline
\end{tabular}


Terlihat pada tabel tersebut bahwa kegiatan menentukan pereaksi pembatas sebesar $71,87 \%$, sehingga kegiatan belajar menentukan pereaksi pembatas menggunakan LKS-Induktif dikategori sedang.

Hasil belajar LKS-Induktif siswa yaitu mendefinisikan pereaksi pembatas sebesar 78,2\%, dan menentukan pereaksi pembatas sebesar 71,87\% diklasifikasikan ke dalam tingkat pemahaman sedang. Keduanya lebih rendah dibandingkan dengan hasil belajar mengingat konsep prasyarat sebesar $88 \%$. Dimungkinkan, perubahan pemahaman konsep siswa sebelum dan sesudah pembelajaran mengenai pereaksi pembatas sebesar 64,50\% tergolong pada kriteria sedang.

Hasil belajar pereaksi pembatas berbantuan LKS-Induktif dengan langkahlangkah kegiatan yaitu 1) mengingat konsep prasyarat sebesar 88\%, 2) mendefinisikan pengertian pereaksi pembatas sebesar 78,2\%, dan 3) menentukan pereaksi pembatas sebesar 71,87\% dirangkum dalam Gambar 1 .

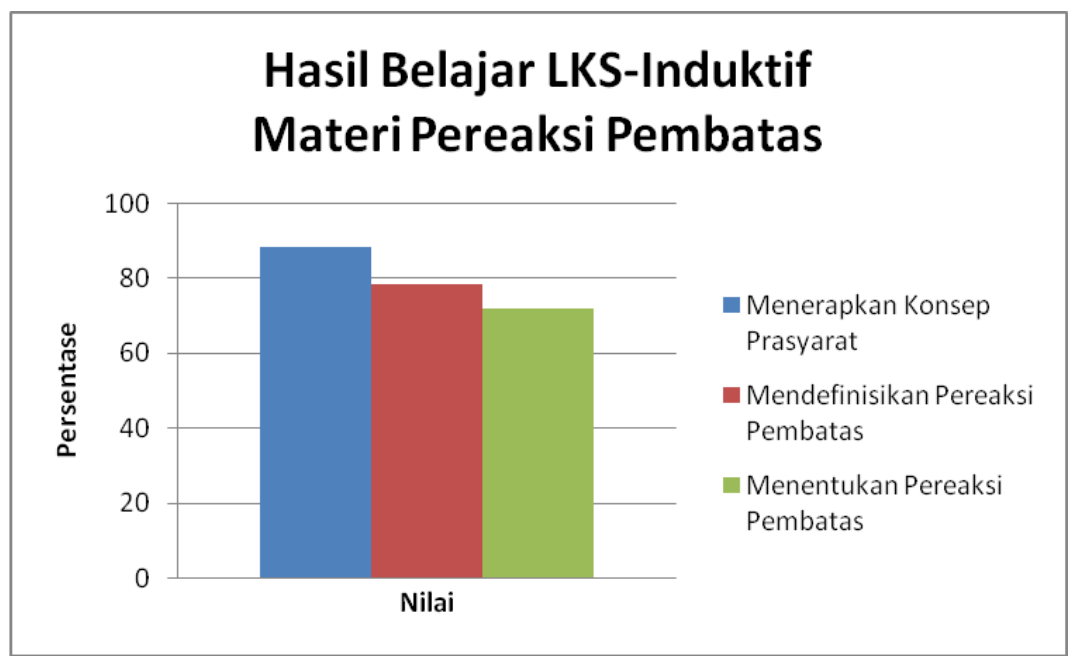

Gambar 1. Histogram Hasil Belajar LKS-Induktif Materi Pereaksi Pembatas

\section{SIMPULAN}

Dari hasil penelitian dapat disimpulkan bahwa: penggunaan LKS-Induktif dapat meningkatkan hasil belajar konsep pereaksi pembatas pada siswa kelas X SMA Negeri 1 Palangka Raya tahun pelajaran 2018/2019. Penggunaan LKSinduktif mendapatkan hasil belajar menerapkan konsep prasyarat sebesar $88 \%$; menentukan konsep pereaksi pembatas sebesar 78,2\% dan menggunakan pereaksi pembatas untuk menentukan massa, volume, zat partikel sebesar 71,87\%. Hasil belajar LKS-Induktif siswa yaitu menentukan pereaksi pembatas sebesar 78,2\%, dan menggunakan pereaksi pembatas sebesar 71,87\% diklasifikasikan ke dalam tingkat pemahaman sedang.

\section{DAFTAR PUSTAKA}

Kean, E. \& Middlecamp, C. 1995. Panduan Belajar Kimia Dasar. Jakarta: Gramedia.

Madjid, Abdul. 2013. Strategi Pembelajaran. Bandung: PT. Remaja Rosdakarya Offset.

Permendiknas No. 81A. 2013. Implementasi Kurikulum. Jakarta: Menteri Pendidikan dan Kebudayaan Republik Indonesia. 
Rivai, Samsiar. 2011. Pengetahuan Konseptual Dan Prosedural Dalam Pembelajaran Perkalian Bilangan Pecah Desimal Berdasarkan Paham Konstruktivisme Pada Siswa SD Kelas V. Diambil pada tanggal 17 Juli 2016, dari ejurnal.fip.ung.ac.id/index.php/PDG/article/viewFile/265/259

Sanjaya, Wina. 2010. Strategi Pembelajaran Berorientasi Standar Proses Pendidikan. Jakarta: Kencana.

Uno, Hamzah. 2006. Model Pembelajaran Menciptakan Proses Belajar yang Kreatif dan Efektif. Jakarta: PT. Bumi Akasara.

Valentie, I. 2019. Pemahaman Konsep Pereaksi Pembatas Hasil Pembelajaran Kimia Menggunakan LKS-Induktif Pada Siswa Kelas X. Jurnal Ilmiah Kanderang Tingang. 10, 1 (Jun. 2019), 12-26. DOI:https://doi.org/10.37304/jikt.v10i1.17. 